\title{
The clinical phenotype of Israeli patients with Q703K mutation in the NLRP3 gene
}

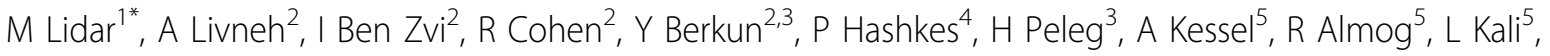 \\ G Slobodin $^{5}$, M Rozenbaum ${ }^{5}, Y$ Shinar $^{2}$ \\ From 8th International Congress of Familial Mediterranean Fever and Systemic Autoinflammatory Diseases \\ Dresden, Germany. 30 September - 3 October 2015
}

\section{Background}

Cryopyrin associated periodic syndromes (CAPS) comprise a spectrum of autoinflammatory disorders of varying severity caused by mutations in the NLRP3 gene. The Q703K allele, reaching 5\% of the total allele count in the general population, is considered either functional polymorphism or a low penetrance mutation

\section{Aim}

To describe the clinical phenotype of the Israeli patients in whom the Q703K allele was found.

\section{Methods}

Ten patients carrying the Q703K mutation were identified among 70 patients in whom the diagnosis of CAPS was suspected on clinical grounds.

\section{Results}

Seven female and 3 male patients with a mean age of $22.5 \pm 17.8$ years and a mean diagnosis delay of 12.4 years were identified. Their clinical characteristics ranged from self resolving attacks of fever, urticaria and arthralgia to a chronic, debilitating steroid-dependent inflammatory disease. Splenomegaly, transfusion-dependent anemia, sensory neuropathy and pericarditis, manifestations which are not included in the traditional CAPS-spectrum, were detected in some of the patients. The majority of patients responded to high dose steroid therapy. DMARDS such as methotrexate, azathioprine and colchicine were generally ineffective at reducing steroid dose or attack rate. Therapy with TNF inhibitors or anti IL-1 agents was instituted in 4 patients with a favorable response. All but one patient needed chronic

${ }^{1}$ Sheba medical center, Rheumatology unit, Ramat gan, Israel Full list of author information is available at the end of the article anti-inflammatory therapy to prevent attacks and reduce steroid dose.

\section{Conclusions}

Our cohort of patients with the Q703K mutation, the largest reported to date, show a heterogeneous inflammatory phenotype, in which a CAPS component may be appreciated. Both IL-1 and TNF inhibitors seem to be effective in treating steroid resistant manifestations of this subgroup of CAPS patients.

\section{Authors' details}

${ }^{1}$ Sheba medical center, Rheumatology unit, Ramat gan, Israel. ${ }^{2}$ Sheba Medical Center, Tel Hashomer, Israel. ${ }^{3}$ Hadassah Medical Center, Jerusalem, Israel. ${ }^{4}$ Shaare Zedek Medical Center, Jerusalem, Israel. ${ }^{5}$ Bnai Zion Medical Center, Haifa, Israel.

Published: 28 September 2015

doi:10.1186/1546-0096-13-S1-P42

Cite this article as: Lidar et al:: The clinical phenotype of Israeli patients with Q703K mutation in the NLRP3 gene. Pediatric Rheumatology 201513 (Suppl 1):P42.

Submit your next manuscript to BioMed Central and take full advantage of:

- Convenient online submission

- Thorough peer review

- No space constraints or color figure charges

- Immediate publication on acceptance

- Inclusion in PubMed, CAS, Scopus and Google Scholar

- Research which is freely available for redistribution

Submit your manuscript at www.biomedcentral.com/submit
() Biomed Central 